ТЕХНІКА ТА МЕТОДИ ЕКСПЕРИМЕНТУ ENGINEERING AND METHODS OF EXPERIMENT

\author{
A. T. Gheith ${ }^{1}$, M. A. El-Sarraf ${ }^{2, *}$, I. E. Hasan ${ }^{1,3}$, N. L. Helal', \\ R. A. Rizk ${ }^{1}$, Amal A. El-Sawy ${ }^{2}$, A. El-Sayed Abdo ${ }^{4}$ \\ ${ }^{1}$ Faculty of Science, Helwan University, Cairo, Egypt \\ ${ }^{2}$ Nuclear \& Radiological Regulatory Authority, Cairo, Egypt \\ ${ }^{3}$ College of Science and Arts at Alnbhaniah, Qassim University, Saudi Arabia \\ ${ }^{4}$ Nuclear Research Centre, Atomic Energy Authority, Cairo, Egypt
}

*Corresponding author: magdsarraf@yahoo.com

\title{
ASSESSMENT OF A POLYMERIC COMPOSITE AS A RADIATION ATTENUATOR AND A RESTORATION MORTAR FOR CRACKING IN BIOLOGICAL SHIELDS
}

This work is dedicated to figuring out robust epoxy/magnetite/boron carbide (EP/Mag/ $\left.{ }_{4} \mathrm{C}\right)$ composite for radiation attenuation at multiple applications related to nuclear installations, as well as restoration mortar for cracking developed in concrete biological shields. The mechanical properties (flexural, compressive, and impact strengths) and the physical properties (water absorption, porosity, and dry bulk density), each, have been performed to label the composite integrity for practical application. In practice, attenuation properties have been performed by using a collimated beam emitted from spontaneous fission ${ }^{252} \mathrm{Cf}(100 \mu \mathrm{g})$ neutron source and neutron gamma spectrometer with stilbene scintillator. The pulse shape discrimination technique which would come of the zero cross over method was used to measure the fast neutron and gamma-ray spectra. Thermal neutron fluxes have been measured by using the thermal neutron detection system and the BF-3 detector. The attenuation parameters: precisely, macroscopic effective removal cross-sections $\Sigma_{R}\left(\mathrm{~cm}^{-1}\right)$, macroscopic cross-sections $\Sigma\left(\mathrm{cm}^{-1}\right)$, and total attenuation coefficients $\mu\left(\mathrm{cm}^{-1}\right)$ of fast and thermal neutrons and total gammarays respectively were evaluated using the attenuation relations. Also, the MCNP5 code and MERCSF-N program have been used to compute the parameters theoretically. When applicable, measured and calculated results were compared, and it tells us a comprehensive agreement.

Keywords: biological shield, composite, neutron and gamma-ray spectra, attenuation parameters, MCNP code.

\section{Introduction}

Any concrete structure may develop structural or non-structural cracks either by aging or by any other cause. Cracks in concrete foundations greater than approximately $1-2 \mathrm{~mm}$ require sealing/injection to prevent the ingress of moisture, oxygen, and other materials $[1,2]$. Also, the nuclear facilities' biological shield concrete structures can deteriorate in one way or another by the impact of increasing temperature as well as radiation exposure. It is quite right to say that irradiation of concrete to nuclear radiation leads to temperature increase, which affects the mechanical, physical, and radiation shielding properties accordingly. Cracks, chips, and breaks or flaking in concrete are not only unsightly but rather, they can lead to further deterioration to the surface $[3,4]$.

To repair concrete, it is important to select the right repair product, because not all products are suited for all purposes. An ideal product suited for general patching may not work well on small cracks and fractures.

Prevailing of polymer consumption encourages the growth of dispersed fillers incorporation to minimize the cost, besides the increase in strength and stiffness of the end composite. The composite's cha- racteristic stems from matrix-filler interaction. Each constituent participates in rendering the composite material performance $[5,6]$.

Epoxy resin provides permanent bonding even for the smallest cracks and cracks ramifications in concrete and masonry - thanks to its high adhesiveness as well as its overall strength. The main advantage of epoxies is their compressive strength, which exceeds most of the concretes at 12,000 psi or greater. On the other hand, epoxies cure very slowly, generally taking hours to harden. This can be an advantage because it allows time for the epoxy to flow into even the smallest crevices [7].

Selecting a radiation shielding media is a rather complex matter since it is supposed to deal with different types of radiation. Gamma-rays as well as neutrons of different energies. Therefore, we should attain a combination of heavy, light, and thermal neutron absorber components. Generally, heavy components (elements) deal with gamma-rays as well as fast neutrons through (inelastic scattering). In addition to that, light components (elements) would be responsible for intermediate neutrons through (elastic scattering). Finally, thermal neutron absorbers: they have a dual role as thermal neutron absorbers and indirectly preventing gammas that could have happened

(C) A. T. Gheith, M. A. El-Sarraf, I. E. Hasan, N. L. Helal, R. A. Rizk, Amal A. El-Sawy, A. El-Sayed Abdo, 2020 
through (heavy elements "Fe") absorption of thermal neutrons [12]. In our work, epoxide formulations provide good neutron attenuation; it has been suggested that it might be also suitable as shields for gamma and $\mathrm{X}$-rays by adding heavy minerals [8]. Magnetite $\left(\mathrm{Fe}_{3} \mathrm{O}_{4}\right)$ having a high density $\left(4.9-5.2 \mathrm{~g} / \mathrm{cm}^{3}\right)$ is an effective shielding material for neutrons and gammarays $[9,10]$. In addition to such high-density aggregate, additives containing boron are sometimes used to improve shielding properties, where boron has been induced as a neutron absorber in various materials in addition to concrete as a general practice; however, some boron compounds influence cement hydration and retard setting if added with high loading fractions to concrete castings, which does not exist in the case of the polymer composite. For instance, borated graphite (a mixture of elemental boron and graphite) has been used in fast reactor shields. Boron has also been added to steel for shield structures to reduce secondary gamma-ray production. In addition to that, boral - consisting of boron carbide and aluminum - has been used for shielding purposes $[11,12]$.

To restore concrete structures to their original strength, the formula is suggested as a repair mortar for developing cracks in the biological shields. This mortar will be satisfying the requirements of improved plastics, such as high mechanical strength, adhesiveness, and reasonable physical properties, besides its main role in radiation shielding for this application.

Recently, many researchers have studied the effect of the dispersed fillers in a variety of polymers, which satisfies the requirements for radiation shielding [13, $14,17]$. The prepared composite $\left(\mathrm{EP} / \mathrm{Mag} / \mathrm{B}_{4} \mathrm{C}\right)$ can be utilized in radiation attenuation with different applications, as an example, for shipping and storage of radionuclide materials for many mobile and stationary sources. Also, it can be used as portable radiation shielding, for example, medical lining for the walls of diagnostic and radiotherapy rooms. Besides, it might foresee applications for detector shields, neutron guides, valves, and pipes [15]. As well, this composite could be applied as rendering/plastering mortar or even coating for shielding structures present in nuclear foundations as a possible example for the many epoxy composites practical uses [16].

The present study has the primary aim of using epoxy, magnetite, and boron carbide to prepare $\mathrm{EP} / \mathrm{Mag} / \mathrm{B}_{4} \mathrm{C}$ formulation for the construction of radiation attenuation shield used for a variety of applications, as well as a mortar for developing cracks in biological concrete shields. Measurements have been carried out to come through their mechanical, physical, and radiation attenuation properties. Also, theoretical calculations have been achieved using MCNP5 and MERCSF-N programs.

\section{Experimental procedure}

\subsection{Materials and sample preparation}

The concerned composite epoxy/magnetite/boron carbide $\left(\mathrm{EP} / \mathrm{Mag} / \mathrm{B}_{4} \mathrm{C}\right)$ was prepared with definite weights in terms of constituents to provide suitable mechanical, physical, and attenuation properties. The standard Bisphenol-A based Epoxy resin (EP) of the commercial name (DGEBA DER 331 product of DOW Chemical Company-USA, with technical purity $95 \%$ and epoxide weight 182-192) hardened by polyoxyporopylendiamine (Cetepox $1465 \mathrm{H}$ product of Chemical \& Technologies for Polymers Co., Egypt) was used to work out the composite base. Magnetite supplied by the Nuclear Materials Authority (El Kattameya, Egypt) in the form of a fine black powder of mesh size $500 \mu \mathrm{m}$ obtained by physical separation from the coastal black sand which was accumulated by the precipitation of weathered heavy minerals along the Nile Valley pathway and boron carbide $\left(\mathrm{B}_{4} \mathrm{C}\right)$ chemical of $-60+230$ mesh (a product of Sigma-Aldrich Ltd, England) were used as composite fillers. First, appropriate Teflon molds were glued to the lab planchettes. Cylindrical molds $(10 \mathrm{~cm}$ in diameter and $\approx 5 \mathrm{~cm}$ in thickness) acting for radiation attenuation measurements and molds of ASTM dimensions for the required mechanical and physical tests. The formulation ingredients (resin - curing agent - fillers) were weighed with an electronic balance and were then mingled together to obtain a homogenous mixture. The constituents where: $\mathrm{EP}=15 \%$, Mag $=75 \%$ and $\mathrm{B}_{4} \mathrm{C}=10 \%$, which stands for the EP/Mag/ $\mathrm{B}_{4} \mathrm{C}$ composite. The elemental composition of both blank and filled formulations was evaluated by the aid of chemical pamphlets and magnetite supplier analysis is given in Table 1 .

Table 1. Chemical composition by weight fraction of the investigated formulations

\begin{tabular}{|c|c|c|c|c|c|c|c|c|c|c|c|}
\hline Sample & $\mathrm{H}$ & $\mathrm{B}$ & $\mathrm{C}$ & $\mathrm{N}$ & $\mathrm{O}$ & $\mathrm{Na}$ & $\mathrm{Mg}$ & $\mathrm{Si}$ & $\mathrm{K}$ & $\mathrm{Ca}$ & $\mathrm{Fe}$ \\
\hline EP & $\begin{array}{l}8 \\
\dot{8} \\
\dot{8}\end{array}$ & & $\begin{array}{l}\frac{2}{f} \\
\vdots \\
0 \\
0\end{array}$ & $\begin{array}{l}\stackrel{2}{0} \\
\stackrel{0}{0} \\
0 \\
0\end{array}$ & 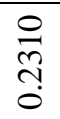 & & & & & & \\
\hline $\mathrm{EP} / \mathrm{Mag} / \mathrm{B}_{4} \mathrm{C}$ & $\frac{\stackrel{?}{\frac{1}{3}}}{\stackrel{0}{0}}$ & $\begin{array}{l}0 \\
0 \\
0 \\
0 \\
0 \\
0\end{array}$ & 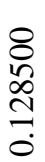 & \begin{tabular}{l}
8 \\
8 \\
\multirow{8}{8}{} \\
8 \\
0
\end{tabular} & 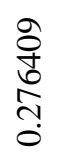 & $\begin{array}{l}\stackrel{8}{0} \\
\stackrel{0}{8} \\
\stackrel{8}{0}\end{array}$ & 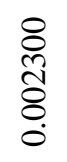 & 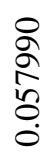 & $\begin{array}{l}\overline{0} \\
\qquad \\
8 \\
8\end{array}$ & $\begin{array}{l}\stackrel{0}{0} \\
\stackrel{0}{0} \\
\stackrel{0}{0}\end{array}$ & \begin{tabular}{l}
8 \\
\multirow{o}{0}{} \\
$\infty$ \\
గn
\end{tabular} \\
\hline
\end{tabular}


We note here that, the sample workability is governed by limitations imposed by the ability of a liquid component (resin + hardener) to accept the reasonable dry component (fillers) percentage without violating the mortar's consistency and fluidity. Afterward, the mixture was degassed to allow the entrapped air bubbles to be released. Finally, it was poured with great care in the specimen's Teflon molds. After curing, the samples were released from molds and left for more than one week to allow the cross-linking process to propagate. The expected cross-linkages were completed. They were furthermore shaped with steel adaptation frames to the final dimensions.

\subsection{Mechanical and physical tests}

The mechanical tests: compressive, bending and Charpy impact strengths have been achieved at room temperature at the National Institute for Standards (NIS) of Egypt. The 400 KN ZWICK Universal Testing Machine (No 15376), with calibrated cell and Charpy impact hammer, were used to perform such experimental tests according to the ASTM D-695, ASTM D-790, and ASTM D-256 designations [18 20]. Dry bulk density, water absorption, and total porosity were measured depending on the ASTM designation (D 570-81) and ASTM designation (C 948-81) re-approved 2001 [21, 22].

\subsection{Fast neutron and gamma-ray measurements}

Fast neutron and total gamma-ray (primary + secondary) spectra have been measured behind cylindrical epoxy blank (EP) and epoxy/magnetite/boron carbide $\left(\mathrm{EP} / \mathrm{Mag} / \mathrm{B}_{4} \mathrm{C}\right)$ composite samples of $10 \mathrm{~cm}$ diameter and different thicknesses. Measured spectra have been carried out by means of a collimated beam emitted from the spontaneous fission ${ }^{252} \mathrm{Cf}(100 \mu \mathrm{g}-$ June 2001) neutron source and neutron gamma spectrometer with cylindrical stilbene scintillator $(\varnothing=4 \mathrm{~cm}$ and thickness $=4 \mathrm{~cm})$. The collimated beam was provided by the narrow beam experimental facility that consisted of the radioactive source + collimator - samples holder - detector + collimator. The arrangement layout is shown elsewhere [13]. The purpose of the beam - detector collimation is to provide a beam of a specific intensity and to divert side scattered radiations from the detector path which would enhance the discrimination capability. The spectrometer components, set up, and discrimination technique happened to be explained in detail elsewhere [23 - 25]. Spectrometer discrimination, linearity, and energy scaling were checked before taking measurements by accumulating spectra of ${ }^{22} \mathrm{Na},{ }^{137} \mathrm{Cs},{ }^{60} \mathrm{Co}$, and $\mathrm{Pu}-\alpha-\mathrm{Be}$ sources. Measured pulse amplitude distributions of the recoil protons or electrons were converted into energy spectra of fast neutrons or gamma- rays using two unfolding codes NSPEC and GSPEC originated on the double differentiation and matrix correction methods for neutrons and gamma-rays respectively $[26,27]$.

\subsection{Slow neutron measurements}

Slow neutron fluxes have been measured behind the concerned epoxy blank (EP) and (EP/Mag/B $\left.{ }_{4} \mathrm{C}\right)$ formulations with different thicknesses using the thermal neutron detection system plugged with the BF-3 (LND-20354) detector. The same experimental layout in section 2.3 was used where BF-3 tube was introduced into the detector collimator given an operating voltage of $1600 \mathrm{~V}$. Output pulses drawn from the BF-3 were fed to the preamplifier, then to the amplifier type ORTEC 572A. The magnified pulses were fed into the PC incorporating a TRUMP $8 \mathrm{~K} / 2 \mathrm{~K}$ data acquisition card. The diagram of the measuring system components was shown elsewhere [28]. The slow neutron $(0-1000 \mathrm{eV})$ fluxes were measured by integrating the specified net area under the peaks 2.31 and $2.79 \mathrm{MeV}$ [29].

\section{Theoretical calculations}

\subsection{MCNP calculation}

MCNP5 computer code was used to reflect a three-dimensional model that matches the experimental setup. For the source term, a built-in card associated with ${ }^{252} \mathrm{Cf}$ spontaneous fission neutron source is quite right to perform the source spectrum. At the detection term, both detectors' interactive regions, stilbene, and BF-3 were introduced to the code and the DXTRAN sphere was embedded within such detection mediums to improve the results' accuracy.

The code is to run using analytical methods starting from the source term till the outer shell of such sphere and continues using the MCNP technique to the central shell. To perform fast and thermal neutrons and gamma-ray calculations, the code was first to run in NP mode followed by P mode. Neutron, as well as induced gamma-ray tallies, was obtained from the first runs while pure photon results could be deduced from the second runs. The total photon term results from the summation of both pure and induced terms. A number of $10^{8} \mathrm{NP}$ and $10^{9} \mathrm{P}$ histories were accumulated to perform the calculations, in which tallies were scaled to ${ }^{252} \mathrm{Cf}$ strength using appropriate tally multiplication cards [30]. The MCNP computer code with (95 energy groups) for fast neutrons and (55 energy groups) for gamma-rays was used to calculate, theoretically, the spectra behind the two formulations (EP and $\mathrm{EP} / \mathrm{Mag} / \mathrm{B}_{4} \mathrm{C}$ ) of thicknesses 19.02 and $20.56 \mathrm{~cm}$ for neutrons and gamma-rays, respectively. The obtained spectra are presented in Figs. 7 - 10. 


\subsection{Macroscopic effective removal cross-section of fast neutrons}

The macroscopic effective removal cross-sections of fast neutrons $\Sigma_{R}\left(\mathrm{~cm}^{-1}\right)$ through both EP and $\mathrm{EP} / \mathrm{Mag} / \mathrm{B}_{4} \mathrm{C}$ formulations have been calculated using the MERCSF-N computer program. In principle, the program had been constructed, verified, and applied for calculating the macroscopic effective removal cross-section $\Sigma_{\mathrm{R}}\left(\mathrm{cm}^{-1}\right)$ of fast neutrons through homogeneous mixtures, compounds, concretes, and composites. To achieve the calculations, atomic masses, and mass removal cross-sections $\Sigma_{R} / \rho$ $\left(\mathrm{cm}^{2} / \mathrm{g}\right)$ for a collection of elements were fed to the program as input physical data. MERCSF-N program; description and confirmation, in details with regards are given elsewhere [31]. The program output illustrates the macroscopic effective removal crosssection $\Sigma_{\mathrm{R}}\left(\mathrm{cm}^{-1}\right)$ of fast neutrons through the con- cerned target. The applications of the program are given in numerous publications, for instance [13, 14]. Results for $\mathrm{EP}$ and $\mathrm{EP} / \mathrm{Mag} / \mathrm{B}_{4} \mathrm{C}$ formulations are presented in Table 4.

\section{Results and discussion}

\subsection{Mechanical properties}

The epoxy blank (EP) and epoxy/magnetite/boron carbide $\left(\mathrm{EP} / \mathrm{Mag} / \mathrm{B}_{4} \mathrm{C}\right)$ mechanical strengths are shown in Table 2. It shows the values of the mechanical properties decrease for the $\mathrm{EP} / \mathrm{Mag} / \mathrm{B}_{4} \mathrm{C}$ than $\mathrm{EP}$ and this is due to the fillers loading fraction. The filler load leads to particle agglomeration which affects the composite consistency and, consequently, lower filler-resin matrix bonding. In other words, particle loading transcends the critical level, called mechanical percolation.

Table 2. Measured mechanical properties for EP and EP/Mag/B 4 C formulations

\begin{tabular}{|c|c|c|c|c|c|}
\hline \multirow{2}{*}{ Sample } & \multicolumn{2}{|c|}{ Bending } & \multicolumn{2}{c|}{ Compression } & Impact \\
\cline { 2 - 6 } & $\begin{array}{c}\text { Flexural strength, } \\
\mathrm{MPa}\end{array}$ & $\begin{array}{c}\text { Modulus } \\
\text { of elasticity, } \\
\mathrm{MPa}\end{array}$ & $\begin{array}{c}\text { Compressive strength, } \\
\mathrm{MPa}\end{array}$ & $\begin{array}{c}\text { Modulus } \\
\text { of elasticity, } \\
\mathrm{MPa}\end{array}$ & $\begin{array}{c}\text { Impact strength, } \\
\mathrm{J} / \mathrm{m}\end{array}$ \\
\hline $\mathrm{EP}$ & 85 & - & 90 & - & - \\
\hline EP/Mag/B $4 \mathrm{C}$ & 31.03 & 9363.96 & 62.82 & 2454 & 142.97 \\
\hline
\end{tabular}

\subsection{Physical properties}

Water absorption, porosity, and dry bulk density for the concerned epoxy blank (EP) and epoxy/magnetite/boron carbide $\left(\mathrm{EP} / \mathrm{Mag} / \mathrm{B}_{4} \mathrm{C}\right)$ composite are presented in Table 3. It is noticed that the $\mathrm{EP} / \mathrm{Mag} / \mathrm{B}_{4} \mathrm{C}$ composite has higher values than those for epoxy blank (EP). It is to say that this may be attributed to the fact that filler incorporation affects composite cross-linking since it introduces pores to the matrix. By comparison to published data [13], the obtained results are reasonable in terms of practical applications.

\section{Table 3. Measured physical properties for EP and EP/Mag/B $\mathbf{B}_{4} \mathrm{C}$ formulations}

\begin{tabular}{|c|c|c|c|}
\hline Sample & Water absorption, \% & Porosity, \% & Dry bulk density, ${\mathrm{g} \cdot \mathrm{cm}^{-3}}^{-1}$ \\
\hline $\mathrm{EP}$ & 0.0106 & 0.0124 & 1.16 \\
\hline $\mathrm{EP} / \mathrm{Mag} / \mathrm{B}_{4} \mathrm{C}$ & 0.0389 & 0.0660 & 2.995 \\
\hline
\end{tabular}

\subsection{Attenuation results}

The measured pulse amplitude distributions of recoil protons and electrons were converted to energy distributions (spectra) of neutrons and gamma-rays, respectively. The observed spectra of fast neutrons exiting epoxy blank $(E P)\left(\rho=1.116 \mathrm{~g} / \mathrm{cm}^{3}\right)$ with thicknesses; bare (0), 4.36, $8.50 \ldots$ and $19.02 \mathrm{~cm}$, and epoxy/magnetite/boron carbide $\quad\left(\mathrm{EP} / \mathrm{Mag} / \mathrm{B}_{4} \mathrm{C}\right)$ $\left(\rho=2.995 \mathrm{~g} / \mathrm{cm}^{3}\right)$ with thicknesses; bare $(0), 4.30,8.56$ $\ldots$ and $20.56 \mathrm{~cm}$, respectively, are displayed in Figs. 1 and 2 . The general trend for the intensity of the neutron spectra is for a decrease versus the increase in energy and formula thickness. Displayed spectra almost have the same shape and profile for both formulations. It is clear, the spectra do not show the buildup of neutrons at low energies, and this may be attributed to the fact that removal of fast neutrons by inelastic scattering is not so effective. Neutrons of energy above the threshold of inelastic scattering are low at the incident beam. It is observed that the spectra depend on the sample thicknesses for neutrons of energies within 1 to $7 \mathrm{MeV}$. For energies above 7 to $9 \mathrm{MeV}$, spectra do not follow regular decrease as detection uncertainty varies for such high energies as shown in both figures.

In Fig. 2, the magnetite effect on the neutron attenuation is clear for all thicknesses and at all energies since the mineral, with mainly iron component, reduces flux through successive cascades of inelastic reactions along the sample. Also, we might need to point out; spectra nearly close-up with increasing the thicknesses for all energies in both figures. This may be attributed to the reduction of the neutron yield with the extension of the formula thickness. 


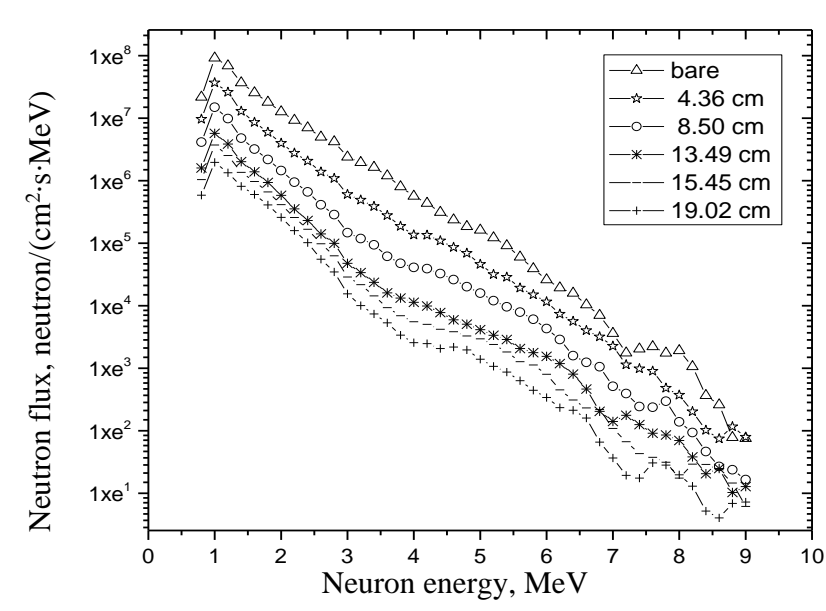

Fig. 1. Measured fast neutron spectra behind EP formula.

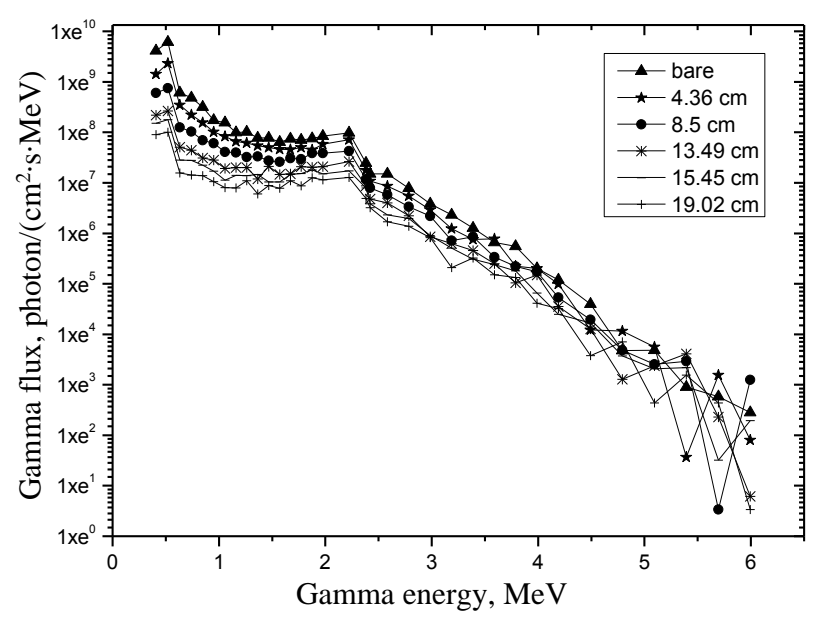

Fig. 3. Measured total gamma-ray spectra behind EP formula.

The total gamma-ray (primary + secondary) spectra behind the concerned formulations with the same thicknesses are displayed in Figs. 3 and 4. The displayed spectra show similarity in shape and profile for all measured thicknesses. The spectra have closely similar profiles: A decrease in intensity with an increase in the photon energy and composite thicknesses. The maxima of the gamma-ray energy working at about $2.225 \mathrm{MeV}$ (in both curves) refers to the contribution of the captured gamma-rays due to the absorption of slow neutrons by hydrogen atoms. It is clear that $\mathrm{EP} / \mathrm{Mag} / \mathrm{B}_{4} \mathrm{C}$ have spectra lower than those for epoxy blank (EP), and this may be attributed to the magnetite and boron carbide effect, i.e. the composite density.

Furthermore, measured fluxes have been integrated over the observed energy range $(0.8$ to $9 \mathrm{MeV}$ ) and $(0.4$ to $6 \mathrm{MeV})$ for fast neutrons and gamma-rays, respectively. For slow neutrons, fluxes have been integrated under the peaks located at 2.31 and $2.79 \mathrm{MeV}$. The integrated values are plotted against the thicknesses and are graphed in Figs. 5 and 6. The attenuation curves Fig. 5 show that fast neutrons and gamma-rays fluxes intensity decrease exponentially with increasing composite thicknesses. The fall-off is the least for gamma rays and greatest for fast neutrons

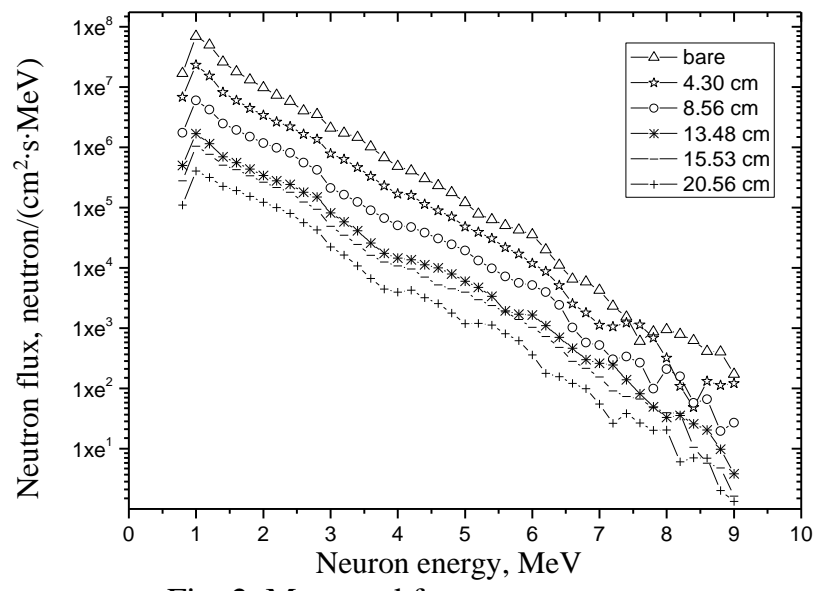

Fig. 2. Measured fast neutron spectra behind EP/Mag/ ${ }_{4} \mathrm{C}$ composite.

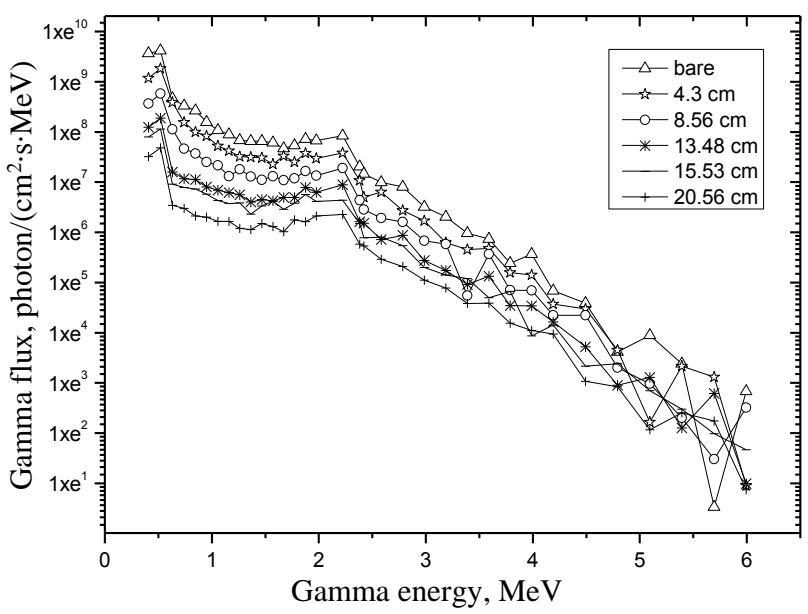

Fig. 4. Measured total gamma-ray spectra behind $\mathrm{EP} / \mathrm{Mag} / \mathrm{B}_{4} \mathrm{C}$ composite.

and both formulations. For EP/Mag/ ${ }_{4} \mathrm{C}$ this may be attributed to the fact that the loss of gamma-rays is compensated by fast and slow neutrons interaction, namely, to the addition to photons economy that comes through neutron inelastic scattering by iron present in magnetite, in addition to the rendered thermal neutron reaction with iron (which gives hard gammas). And soft gammas from thermal neutron reaction with boron present in $\mathrm{B}_{4} \mathrm{C}$. Also, for $\mathrm{EP}$, the fast neutron will react with epoxy components (mainly carbon and oxygen) through elastic scattering, giving gammas indirectly. In addition to the $2.23 \mathrm{MeV}$ radiative capture gamma-rays from thermal neutron reaction with hydrogen; rendering, finally, to increase in gamma-rays in total. All this results in lower attenuation for gamma-rays. The usual attenuation relations were used to obtain the macroscopic effective removal cross-sections $\Sigma_{\mathrm{R}}\left(\mathrm{cm}^{-1}\right)$ and total attenuation coefficients $\mu\left(\mathrm{cm}^{-1}\right)$. Fig. 6 presents the attenuation relations of slow neutrons where the fluxes intensity decreases exponentially with increasing composite thicknesses. Such relations were used to evaluate the macroscopic cross-sections $\Sigma\left(\mathrm{cm}^{-1}\right)$. The absorption effect is clear for slow neutrons by $\mathrm{B}_{4} \mathrm{C}$ in the case of $\mathrm{EP} / \mathrm{Mag} / \mathrm{B}_{4} \mathrm{C}$ composite. 


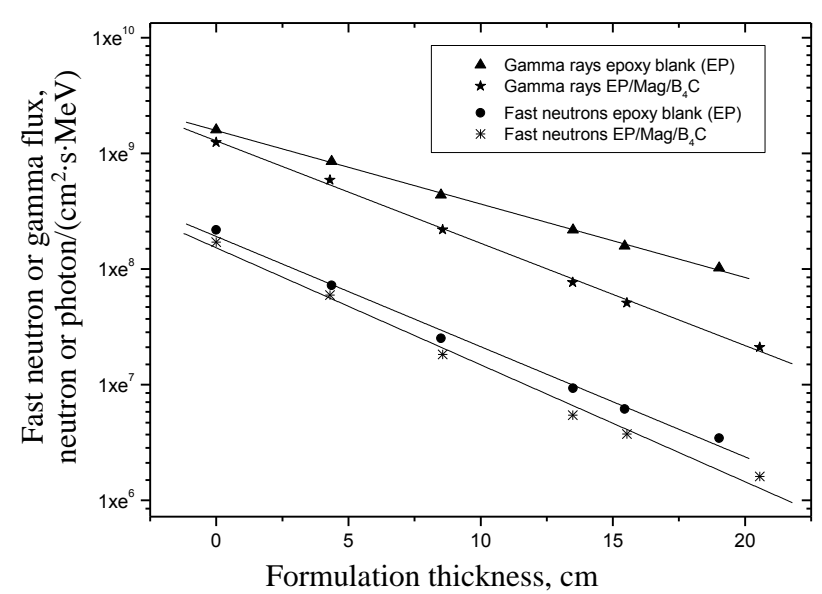

Fig. 5. Measured fast neutron and total gamma-ray fluxes behind $\mathrm{EP}$ and $\mathrm{EP} / \mathrm{Mag} / \mathrm{B}_{4} \mathrm{C}$ formulations.

The obtained experimental and theoretical (MCNP5 and MERCSF-N) shielding attenuation parameters, macroscopic effective removal cross-sections $\Sigma_{\mathrm{R}}\left(\mathrm{cm}^{-1}\right)$, macroscopic cross-sections $\Sigma\left(\mathrm{cm}^{-1}\right)$, and total attenuation coefficients $\mu\left(\mathrm{cm}^{-1}\right)$ of fast and

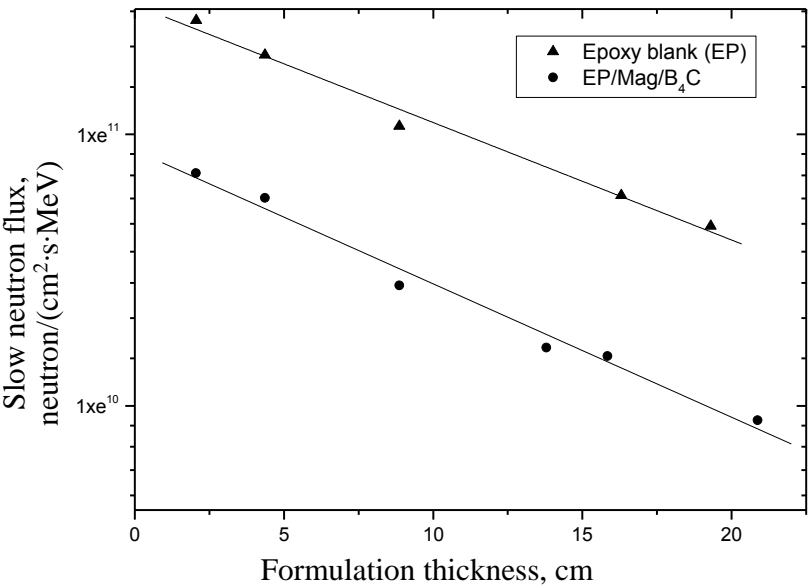

Fig. 6. Measured slow neutron fluxes behind $\mathrm{EP}$ and $\mathrm{EP} / \mathrm{Mag} / \mathrm{B}_{4} \mathrm{C}$ formulations.

slow neutrons and total gamma-rays respectively are shown in Table 4. In addition, it is noticed that measured and theoretically evaluated parameters are close and this confirms the obtained results, as well as the measurement and calculation methods.

Table 4. Measured and calculated attenuation parameters for EP and EP/Mag/B4C formulations

\begin{tabular}{|c|c|c|}
\hline Attenuation parameter, $\mathrm{cm}^{-1}$ & EP & EP/Mag/B ${ }_{4} \mathrm{C}$ \\
\hline$\Sigma_{\text {R-Meas }}$ & $0.09531 \pm 0.00373$ & $0.11295 \pm 0.00196$ \\
\hline$\Sigma_{\text {R-MCNP }}$ & $0.12348 \pm 0.00271$ & $0.13853 \pm 0.00396$ \\
\hline$\Sigma_{\text {R-MERCSF }}$ & 0.10335 & 0.12060 \\
\hline$\mu_{\text {Meas }}$ & $0.06353 \pm 0.00108$ & $0.09457 \pm 0.00185$ \\
\hline$\mu_{\text {MCNP }}$ & $0.05094 \pm 0.00456$ & $0.08245 \pm 0.00255$ \\
\hline$\Sigma_{\text {Meas }}$ & $0.05373 \pm 0.01557$ & $0.05832 \pm 0.00722$ \\
\hline$\Sigma_{\text {MCNP }}$ & $0.05551 \pm 0.00146$ & $0.05736 \pm 0.00299$ \\
\hline
\end{tabular}

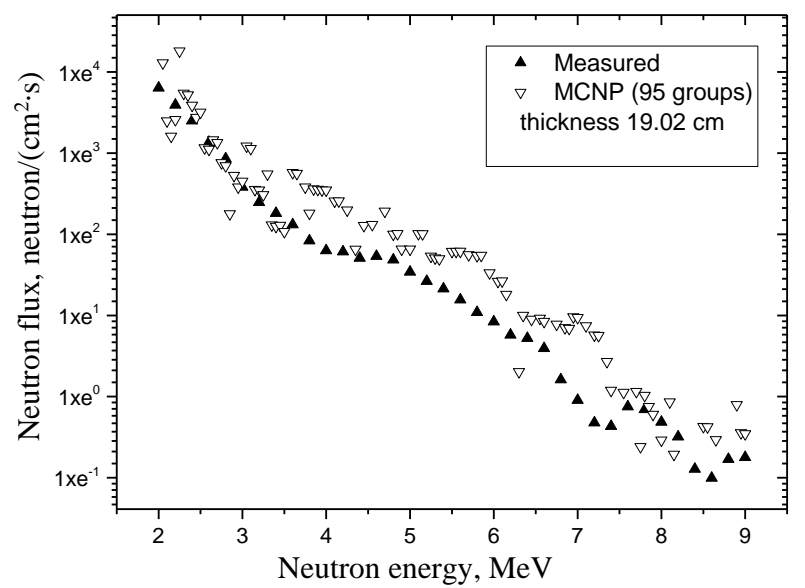

Fig. 7. Measured and calculated (MCNP - 95 energy groups) fast neutron spectra behind EP sample.

Figs. 7 - 10 present a comparison between the experimentally measured spectra and theoretically calculated ones using MCNP5 code for fast neutrons (95 energy groups) and total gamma-rays (55 energy

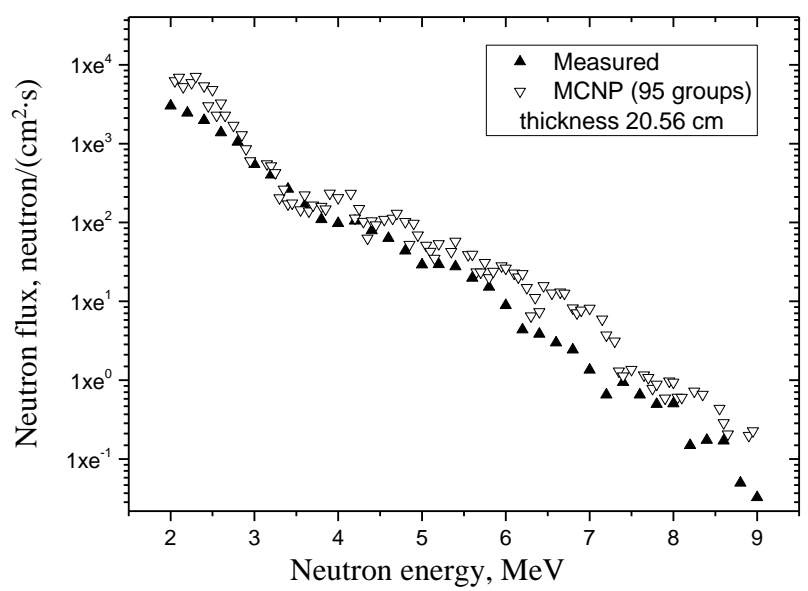

Fig. 8. Measured and calculated (MCNP - 95 energy groups) fast neutron spectra behind $\mathrm{EP} / \mathrm{Mag} / \mathrm{B}_{4} \mathrm{C}$ sample.

groups) behind the two formulations (EP and $\mathrm{EP} / \mathrm{Mag} / \mathrm{B}_{4} \mathrm{C}$ ) of thicknesses 19.02 and $20.56 \mathrm{~cm}$, respectively. It shows that there is a fair resemblance between experimental and theoretical spectra. 


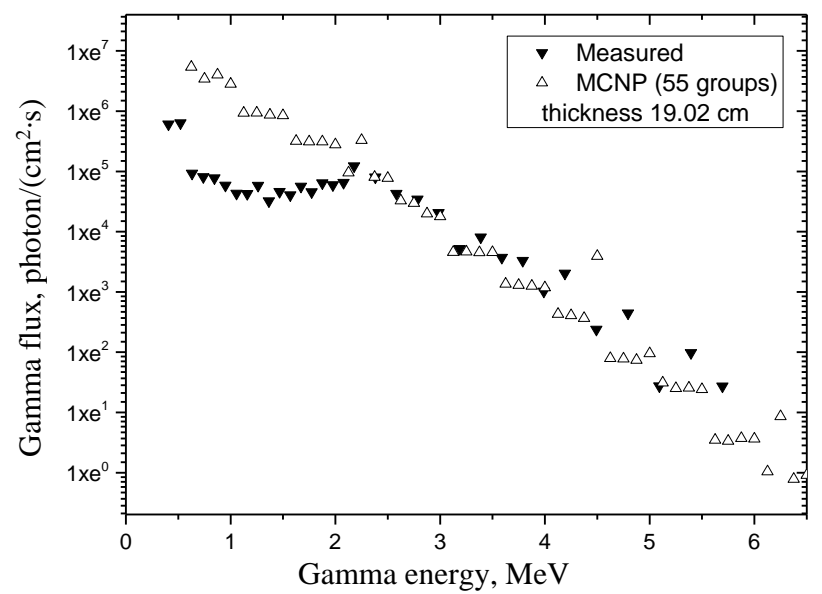

Fig. 9. Measured and calculated (MCNP - 55 energy groups) total gamma spectra behind EP sample.

\section{Conclusions}

From the measured and calculated results for EP and $\mathrm{EP} / \mathrm{Mag} / \mathrm{B}_{4} \mathrm{C}$ formulations, it can be concluded that the measured mechanical properties for $\mathrm{EP} / \mathrm{Mag} / \mathrm{B}_{4} \mathrm{C}$ composite are less than EP formula, while the physical properties for $\mathrm{EP} / \mathrm{Mag} / \mathrm{B}_{4} \mathrm{C}$ are higher versus EP. However, the obtained measurement results are reasonable in terms of practical applications. Besides, fast neutron and total gamma-ray spectra decrease with the increase of energy and formulation thicknesses. This supports the general rules of shielding, which states that a combination of materials is required; heavy material, light material, and thermal neutron absorbing agent would be necessary. The attenuation relations for fast and slow neutrons and total gamma-rays show the fluxes to exponentially decrease with the increase of the formulation thicknesses. The measured and calculated attenuation parameters; $\Sigma_{\mathrm{R}}\left(\mathrm{cm}^{-1}\right), \Sigma\left(\mathrm{cm}^{-1}\right)$, and $\mu\left(\mathrm{cm}^{-1}\right)$ for fast

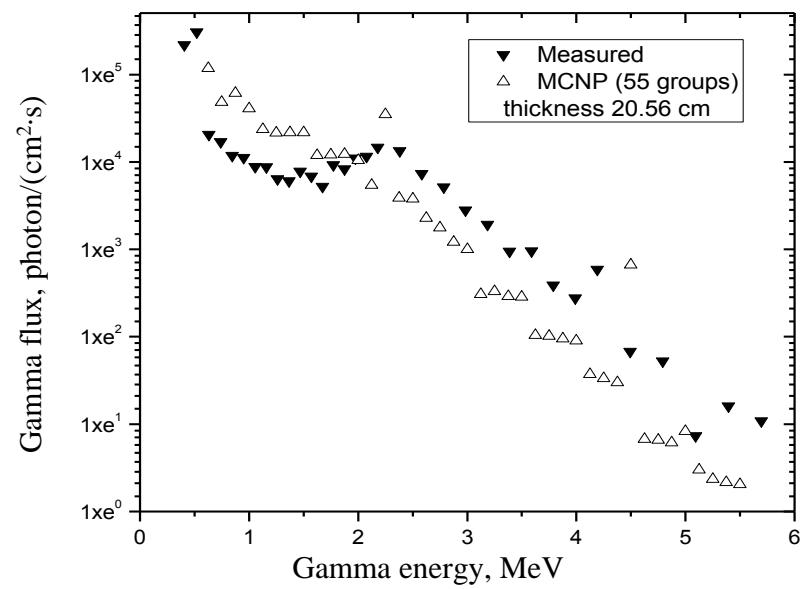

Fig. 10. Measured and calculated (MCNP - 55 energy groups) total gamma spectra behind $\mathrm{EP} / \mathrm{Mag} / \mathrm{B}_{4} \mathrm{C}$ sample.

and thermal neutrons and total gamma-rays respectively through $\mathrm{EP}$ and $\mathrm{EP} / \mathrm{Mag} / \mathrm{B}_{4} \mathrm{C}$ are in reasonable agreement, which confirms the measurement and calculation methods. As well, experimentally, and theoretically MCNP5 obtained spectra of fast neutrons and total gamma-rays behind certain thicknesses of formulations ( $\mathrm{EP}$ and $\mathrm{EP} / \mathrm{Mag} / \mathrm{B}_{4} \mathrm{C}$ ) display a fair resemblance, which confirms the experimental and theoretical methods. The obtained attenuation parameters in Table 4, either measured or calculated, are all giving preference to the $\mathrm{EP} / \mathrm{Mag} / \mathrm{B}_{4} \mathrm{C}$ composite for attenuation of fast, thermal neutrons and gamma-rays. This supports, the created $\mathrm{EP} / \mathrm{Mag} / \mathrm{B}_{4} \mathrm{C}$ composite offers good mechanical, physical, and attenuation properties for many shielding applications, and could be proposed as an injecting mortar for cracks in biological shields. However, further investigations are planned for different filler ratios, for comparison purposes, in order to reach optimal shielding properties.

\section{REFERENCES}

1. R.T.L. Allen, S.C. Edwards. The Repair of Concrete Structure (Glasgow: Blackie, 1987).

2. P.K. Mukherjee, J.J. Deans. Service Performance of Nuclear Containment Concrete. Concrete International - Design \& Construction 10(12) (1988) 75.

3. C.E. Acevedo, M.G. Serrato. Determining the Effects of Radiation on Aging Concrete Structures of Nuclear Reactors. Proc. WM2010 Conf. Phoenix, AZ, March 7 - 11, 2010, Paper 10243.

4. S. Granata, A. Montagnini. Studies on behavior of concretes under irradiation. In: Concrete for Nuclear Reactors. Vol. 2 of Special Publication SP-34 (American Concrete Institute, 1972) p. 1163.

5. M. Xanthos. Functional Fillers for Plastics. 2-nd ed. (New York: John Wiley \& Sons, 2010).

6. M.C.Y. Niu. Composite Airframe Structures: Practical Design Information and Data (Hong Kong: Conmilit Press Ltd, 1992).
7. D.-H. Kim. Composite Structures for Civil and Architectural Engineering (London, Glasgow, New York, Tokyo: E \& FN Spon, 1995).

8. H.S. Katz, J.V. Mileweski (Eds.). Handbook of Fillers for Plastics (New York: Van Nostrand, Reinhold Co., 1987).

9. I.I. Bashter, A. El-Sayed Abdo, M.S. Abdel-Azim. Magnetite ores with steel or basalt for concrete radiation shielding. Jpn. J. Appl. Phys. 36 (1997) 3692.

10. A. El-Sayed Abdo, R.M. Megahid. Homogeneous and multilayered shields for neutrons and gamma rays. Jpn. J. Appl. Phys. 40 (2001) 2460.

11. A.E. Profio. Radiation Shielding and Dosimetry (USA: Awidely-Interscience publication, a division of John Wiley and Sons, 1979).

12. S. Glasstone, A. Sesonske. Nuclear Reactor Engineering. 3-rd ed. (Delhi, India: CBS Publishers \& Distributors, 1986).

13. M.A. El-Sarraf, A. El-Sayed Abdo. Insulating 
epoxy/barite and polyester/barite composites for radiation attenuation. Appl. Rad. Isot. 79 (2013) 18.

14. M.A. El-Sarraf, A. El-Sayed Abdo. Influence of magnetite, ilmenite and boron carbide on radiation attenuation of polyester composites. Rad. Phys. Chem. 88 (2013) 21.

15. A. El-Sayed Abdo, M.A.M. Ali, M.R. Ismail. Influence of magnetite and boron carbide on radiation attenuation of cement-fiber/composite. Ann. Nucl. Energy 30(4) (2003) 391.

16. H. Lee, K. Neville. Handbook of Epoxy Resins (New York: McGraw- Hill Book, 1987).

17. A. El-Sayed Abdo, M.A. El-Sarraf, F.A. Gaber. Utilization of ilmenite/epoxy composite for neutrons and gamma rays attenuation. Ann. Nucl. Energy 30(2) (2003) 175.

18. ASTM. Standard Test Method for Compressive Properties of Rigid Plastics. ASTM Designation 695 (1991).

19. ASTM. Standard Test Methods for Flexural Properties of Un-Reinforced and Reinforced Plastics and Electrical Materials. ASTM Designation 790 (1990).

20. ASTM. Standard Test Methods for Impact Resistance of Plastics and Electrical Insulating Materials. ASTM Designation 256 (1990).

21. ASTM. Standard Test Method for Water Absorption of Plastics. ASTM Designation 570-81 (1981).

22. ASTM. Standard Test Method for Dry and Wet Bulk Density, Water Absorption, and Apparent Porosity of Thin Sections of Glass-Fibre Reinforced Concrete. ASTM Designation C 948 - 81 (1981).
23. R.A. Winyard, J.E. Lutkin, G.W. McBeth. Pulse shape discrimination in inorganic and organic scintillators. Nucl. Instrum. Meth. 95(1) (1971) 141.

24. T.G. Miller. Measurement of pulse shape discrimination parameters for several scintillators. Nucl. Instrum. Meth. 63(1) (1968) 121.

25. I.I. Bashter, A.S. Makarious, A. El-Sayed Abdo. Investigation of hematite-serpentine and ilmenite limonite concretes for reactor radiation shielding. Ann. Nucl. Energy 23(1) (1996) 65.

26. M.E. Toms. A computer analysis to obtain neutron spectra from an organic scintillator. Nucl. Instrum. Meth. 92(1) (1971) 61.

27. Yu.I. Kolevatov, V.I. Kukhtevich, I.V. Goryachev. Scintillation gamma spectrometry with stilbene crystal. Voprosy Dozimetrii i Zashchity ot Izlucheniya 10 (1969) 131. (Rus)

28. A. El-Sayed Abdo, M.A.M. Ali, M.R. Ismail. Natural fibre high-density polyethylene and lead oxide composites for radiation shielding. Rad. Phys. Chem. 66(3) (2003) 185.

29. G.F. Knoll. Radiation Detection and Measurement. 4-th ed. (New York: John Wiley \& Sons, 2010).

30. X-5 Monte Carlo Team. MCNP - A general Monte Carlo Code for Neutron and Photon Transport. Version 5 (Los Alamos National Laboratory, USA, 2005).

31. A.M. El-Khayatt, A. El-Sayed Abdo. MERCSF-N: A program for the calculation of fast neutron removal cross sections in composite shields. Ann. Nucl. Energy 36(6) (2009) 832.

\author{
А. Т. Гейт ${ }^{1}$, М. А. Ель-Сарраф ${ }^{2, *}$, І. Е. Хасан ${ }^{1,3}$, Н. Л. Хелал ${ }^{2}$, \\ Р. А. Різк ${ }^{1}$, Амаль А. Ель-Саві ${ }^{2}$ А. Ель-Сайсд Абдо \\ ${ }^{1}$ Природничий факультет Університету Хелуана, Каїр, Сгипет \\ ${ }^{2}$ Адміністрачія регулювання ядерної та радіологічної безпеки, Каїр, Сгипет \\ ${ }^{3}$ Коледж науки і мистецтвв, Університет Кассім, Саудівська Аравія \\ ${ }^{4}$ Центр ядерних досліджень, Управління атомної енергії, Каїр, Сгипет
}

*Відповідальний автор: magdsarraf@yahoo.com

\title{
ОЦНКА ПОЛІМЕРНОГО КОМПОЗИТА ЯК ОСЛАБЛЮВАЧА РАДІАЦІЇ ТА РЕСТАВРАЦЙНОГО РОЗЧИНУ ДЛЯ ВІДНОВЛЕННЯ РОЗТРІСКУВАНЬ У БІОЛОГІЧНОМУ ЗАХИСТІ
}

Ця робота присвячена дослідженню стійкого композиційного матеріалу на основі епоксиду/магнетиту/карбіду бору $\left(\mathrm{EP} / \mathrm{Mag} / \mathrm{B}_{4} \mathrm{C}\right)$ для ослаблення радіаційного випромінювання при багатьох застосуваннях, пов'язаних 3 ядерними установками, а також розчину для усунення розтріскувань у бетонному біологічному захисті. Було досліджено механічні властивості (міцність на вигин, стиск та ударна міцність) та фізичні властивості (водопоглинання, пористість та насипна щільність) для визначення придатності композиту для практичного застосування. Ослаблення радіації вимірювалося за допомогою колімованих пучків нейтронів, що випромінювалися при спонтанному поділі ${ }^{252} \mathrm{Cf}$ (100 мкг), та спектрометра гамма-квантів і нейтронів із стильбеновим сцинтилятором. Використовувалася дискримінація за формою імпульсу з використанням методу нульового перетину для отримання спектрів швидких нейтронів та гамма-квантів. Потоки теплових нейтронів вимірювали за допомогою системи детектування теплових нейтронів з детектором ВF-3. Параметри ослаблення, а саме: макроскопічні ефективні поперечні перерізи $\Sigma_{\mathrm{R}}\left(\mathrm{cm}^{-1}\right)$, макроскопічні перерізи $\Sigma\left(\mathrm{cm}^{-1}\right)$ та загальні коефіцієнти ослаблення $\mu\left(\mathrm{cm}^{-1}\right)$ швидких та теплових нейтронів та гамма-квантів оцінювалися за допомогою відповідних співвідношень. Для теоретичного обчислення параметрів використовували програми MCNP5 та MERCSF-N. Виміряні та розраховані результати порівнювалися, коли це було можливо, і порівняння свідчить про їхню гарну згоду.

Ключові слова: біологічний захист, композит, спектри нейтронів та гамма-квантів, параметри ослаблення, програма MCNP.

Надійшла/Received 27.02.2020 